\title{
Mirror therapy and self-care autonomy after stroke: an intervention program
}

Terapia por caixa de espelho e autonomia no autocuidado após acidente vascular cerebral: programa de intervenção

Terapia por caja espejo y autonomía en el autocuidado después de un accidente cerebrovascular: programa de intervención

Pedro de Oliveira e Castro*; Maria Manuela Ferreira Pereira da Silva Martins**; Glória Maria Andrade do Couto**; Maria Gorete Reis ${ }^{* * * *}$

\begin{abstract}
Background: In patients with middle cerebral artery (MCA) stroke, changes in upper limb function lead to dependence on others for self-care. In the process of recovering autonomy/independence, there is evidence on the effectiveness of sensory stimulation techniques in the motor recovery after stroke.

Objective: To assess the effect of mirror therapy on the self-care autonomy of patients with hemiplegia/hemiparesis due to MCA stroke.

Methodology: Cross-sectional and quasi-experimental study with a quantitative approach, a before-and-after design, and a non-equivalent control group. A nonprobability sample of 30 participants was selected.

Results: Gains in grip strength, joint range of motion, and manual dexterity of the upper limb were more significant in the experimental group but without statistically significant differences between groups.

Conclusion: Despite the more significant evolution of the experimental group, mirror therapy was not effective in the motor recovery of the upper limb. Further studies are needed in this area using randomized designs, larger samples, and focused on self-care.
\end{abstract}

Keywords: self care; stroke; rehabilitation nursing; mirror therapy

\section{Resumo}

Enquadramento: Nos doentes com acidente vascular cerebral (AVC) da artéria cerebral média (ACM), a alteração da funçáo do membro superior conduz à dependência no autocuidado. No processo de reconstrução da autonomia/independência, existe evidência da efetividade dos métodos com estímulos sensoriais na recuperação motora após o AVC.

Objetivo: Avaliar o contributo da terapia por caixa de espelho para a autonomia no autocuidado nos doentes com hemiplegia/hemiparesia, por AVC da ACM.

Metodologia: Estudo transversal, quase-experimental, com abordagem quantitativa, desenho pré-programa/ pós-programa com grupo controlo não equivalente. Amostra não probabilística de 30 participantes.

Resultados: Verificaram-se ganhos na força de preensão, amplitude articular e destreza manual do membro superior, mais expressivos no grupo experimental mas sem diferenças estatisticamente significativas entre grupos.

Conclusáo: Apesar da evolução mais expressiva do grupo experimental, a terapia por caixa de espelho nâo se revelou efetiva na recuperação motora do membro superior, pelo que, é necessário continuar a investigaçáo nesta área com desenhos randomizados, amostras maiores e direcionada para o autocuidado.

Palavras-chave: autocuidado; acidente vascular cerebral; enfermagem em reabilitação; terapia por caixa de espelho

*MSc., Nurse Specialist in Rehabilitation Nursing, ACES Porto-Ocidental: Community Care Unit of Baixa do Porto, 4000-302, Porto, Portugal pedrojunvor.1984@gmail.com]. Contribution to the article: literature search, experimentation; data collection, treatment and statistica assessment; data analvsis and discussion; article writing. Address for correspondence: Travessa dos Casais, nº 602 - Atães, 4800-230, Guimarães, Portugal.

**Ph.D. Coordinating Professor, Nursing School of Porto, 4200-072, Porto, Portugal [mmar tins@esenf.pt].Contribution to the article: statistical treatment and assessment; data analysis and discussion; article writing

***:MSc, Nurse Specialist in Rehabilitation Nursing Community Care Unit of Paredes Rebordosa, 4580-029, Paredes, Portugal [gloria.a.couto@gmail.com]. Contribution to the article: data analysis and discussion, article writing.

****:Ph.D., Coordinating Professor, São João de Deus School of Nursing, 7000-811, Évora, Portugal [greis@uevora.pt].Contribution to the article: discussion, article writing.

\section{Resumen}

Marco contextual: En los pacientes que han sufrido un accidente cerebrovascular (ACV) en la arteria cerebral media (ACM), la alteración de la función del miembro superior lleva a ser dependientes en el autocuidado. En el proceso de reconstrucción de la autonomía/independencia, existen pruebas de la efectividad de los métodos con estímulos sensoriales en la recuperación motora después del ACV.

Objetivo: Evaluar la contribución de la terapia por caja espejo para la autonomía en el autocuidado en los pacientes con hemiplejia/hemiparesia por ACV de la ACM. Metodología: Estudio basado en el paradigma cuantitativo, de naturaleza transversal y carácter cuasiexperimental, con un diseńo preprograma/posprograma con un grupo de control no equivalente. Muestra de 30 participantes sin repartir aleatoriamente.

Resultados: Se observaron beneficios en la fuerza de prensión, amplitud articular y destreza manual del miembro superior, más llamativos en el grupo experimental pero sin diferencias estadísticamente significativas entre grupos. Conclusión: A pesar de la evolución más llamativa del grupo experimental, la terapia por caja espejo no se mostró efectiva en la recuperación motora del miembro superior, por lo que es necesario continuar la investigación en esta área con diseños aleatorizados, muestras mayores y dirigida al autocuidado.

Palabras clave: autocuidado; accidente cerebrovascular; enfermería en rehabilitación; terapia por caja de espejo

Received for publication: 19.10 .17

Accepted for publication: 05.04 .18 


\section{Introduction}

The ability to adapt to changes is put to the test during the health/disease transition processes which threaten self-care autonomy throughout the lifecycle. Knowing and understanding how these patients perceive and experience their new condition is essential for rehabilitation nurses to develop strategies aimed at facilitating the health/disease transition process and ensuring these patients' adaptation to their new health condition.

The major stroke sequelae are physical and cognitive impairments, together with emotional changes which have an impact on selfcare independence. With regard to middle cerebral artery (MCA) stroke, one of its most disabling sequelae is the changes in the upper limb function, which influence the performance of activities of daily living (ADL; Kim, Lee, Kim, Lee, \& Kim, 2016). The recovery of the upper limb function is an important goal during rehabilitation and a focus of attention of rehabilitation nurses.

Although Gurbuz, Afsar, Aias, and Cosar (2016) argue that conventional treatment methods are insufficient in achieving this goal, a systematic review by Thieme Mehrholz, Pohl, Behrens, and Dohle (2012) and, more recently, a meta-analysis by Zeng, Guo, Wu, Liu, and Fang (2018) have provided evidence on the effectiveness of sensory stimulation methods such as mirror therapy in the upper limb motor recovery after stroke. The same authors stated that the content and number of published articles is not sufficient to draw a robust conclusion and argue for the need to conduct studies with larger samples, a controlled and randomized design, and focused on ADL. Therefore, the purpose of this study was to assess the impact of mirror therapy on the self-care autonomy of patients with hemiplegia/hemiparesis due to MCA stroke. To this end, an intervention program was designed in which the mirror therapy was integrated into a conventional rehabilitation program.

\section{Background}

A stroke occurs when blood flow to the brain is interrupted by a blockage or rupture in a blood vessel (Organização Mundial da Saúde [OMS], 2009).

Stroke-related neurological damage has no direct association with the type of stroke, but rather with the location, extension, and laterality of the stroke lesion. The most common vessel involved is the MCA, followed by the internal carotid artery, with the other vessels being rarely affected (Umphred, 2010).

Lundy-Ekman (2008) underlines that more than $90 \%$ of strokes occur in the MCA territory, causing significant neurological deficits such as contralateral hemiparesis and hemianesthesia, particularly in the upper limb. Upper limb functional loss complicates the performance of ADL, compromising self-care independence. For this reason, the recovery of the upper limb function is an important goal during rehabilitation after stroke (Gurbuz et al., 2016).

Therefore, the focus is on the person who, after an event causing self-care dependence, experiences a transition and begins a process of adaptation to recover their autonomy/independence. In this process, nurses should develop and further enhance new rehabilitation therapies to meet the patients' specific needs for recovery of their health and well-being (Meleis, 2007; Ribeiro, Pinto, \& Regadas, 2014).

The aim of new approaches and treatment methods in stroke rehabilitation is to reactivate the plasticity characteristics of the brain to regain the lost brain functions (Gurbuz et al., 2016). One of these new approaches is the mirror therapy, a sensory stimulation technique with proven effectiveness in the recovery of motor function of the upper extremity (Zeng et al., 2018), for which reason it was integrated into the prescribed intervention program.

The clinical use of mirror therapy - mirror visual feedback - was initially introduced by Ramachandran and Rogers-Ramachandran (1996) to alleviate phantom limb pain and, subsequently, treat hemiparesis after stroke (Thieme, Mehrholz, et al., 2012). The underlying principle is that the movements of the non-affected limb alter the excitability of the ipsilateral motor cortex and improve the motor function of the affected limb.

Ramachandran and Rogers-Ramachandran 
(1996) underline that the use of the external perspective (the visual stimulus), associated with the performance of exercises, can change the performance of a motor task as a result of physiological and plastic alterations of the brain in cortical sensorimotor areas.

According to Machado et al. (2011), the idea is to reeducate the brain through a simple task. Patients perform a series of movements with the healthy arm and watch the reflection in the mirror placed in their sagittal plane as if it were the affected arm. As a result of this visual illusion provided by the mirror box, patients feel as if their two limbs are moving simultaneously and symmetrically, activating both brain hemispheres and increasing the excitability of the affected upper limb. This will be the basis of a neurological mechanism for inducing brain plasticity (Park, Chang, Kim, $\&$ An, 2015) because the brain can readjust itself functionally (neuroplasticity), by reorganizing the cortical maps that contribute to stroke recovery.

The benefits of using mirror therapy in stroke rehabilitation in areas related to $\mathrm{ADL}$, visuospatial neglect, pain, and sensorimotor function of the upper limb are described in 14 randomized studies with 567 participants (Thieme, Mehrholz, et al., 2012). Studies by Lim, Lee, Yoo, Yun, and Hwang (2016) and Kim et al. (2016) corroborate this idea, demonstrating the effectiveness of mirror therapy in the recovery of the motor function of the upper limb and the performance of ADL after stroke.

In this context, mirror therapy should be used in stroke rehabilitation because it can be easily implemented at reduced costs, it is well-accepted, and it can be implemented at the patient's home.

In addition to the need for controlled and randomized studies on self-care with larger samples, these were some of the reasons which contributed to the decision to conduct a study on this topic.

\section{Hypotheses}

H1: Participants in the experimental group have higher hand and pinch grip strength than those in the control group after the program.
$\mathrm{H} 2$ : Participants in the experimental group have higher range of motion of upper limb joint than those in the control group after the program.

H3: Participants in the experimental group have higher static sitting balance than those in the control group after the program.

H4: Participants in the experimental group have higher manual dexterity than those in the control group after the program.

H5: Participants in the experimental group have less pain than those in the control group after the program.

H6: Participants in the experimental group have a lower degree of extinction/inattention than those in the control group after the program.

H7: Participants in the experimental group have a higher degree of autonomy/independence in the self-care activity hygiene and grooming than those in the control group after the program.

H8: Participants in the experimental group have a higher degree of autonomy/independence in the self-care activity bathing than those in the control group after the program. H9: Participants in the experimental group have a higher degree of autonomy/independence in the self-care activity dressing/undressing than those in the control group after the program.

H10: Participants in the experimental group have a higher degree of autonomy/independence in the self-care activity feeding than those in the control group after the program.

\section{Methodology}

The non-identification of studies published in this area or studies published by renowned Portuguese experts led to the development of an intervention program which integrated mirror therapy into a conventional rehabilitation program. First, a literature review was conducted. The search was performed in online databases and search engines, such as B-ON, EBSCO, and PubMed, using Medical Subject Headings $(\mathrm{MeSH})$ terms as concepts and keywords. Thus, the search included full-text articles published between 2008 and 2018 in online databases such as Cumulative Index to Nursing and $\mathrm{Al}$ lied Health Literature (CINAHL), Medical 
Literature Online (MEDLINE) and Cochrane Database of Systematic Reviews (CDSR). The included studies were selected after the application of inclusion and exclusion criteria.

A total of 73 articles were identified in different databases. Eighteen were excluded for being duplicates, 24 based on title reading, nine based on abstract reading, and eight based on full-text reading. Twelve primary studies, a meta-analysis, and a systematic review were included in the literature review. Based on this literature review, the intervention apply mirror therapy of the perform type was integrated into the conventional rehabilitation program after stroke and administered following the steps described in Table 1. Thus, the intervention program entitled self-care and mirror therapy was developed.

Table 1

Procedure for application of the mirror therapy

\begin{tabular}{ll}
\hline Steps & \multicolumn{1}{c}{ Guidelines } \\
\hline Space organization & $\begin{array}{l}\text { Place the mirror in the patient's sagittal plane with the reflecting surface facing the } \\
\text { non-affected upper limb and the affected limb facing the non-reflecting side. }\end{array}$ \\
\hline Participant & The patient is instructed to move the non-affected upper limb and watch the action \\
orientation & reflection in the mirror. Simultaneously, if paresis/paralysis allow it, the patient should \\
try to move the affected limb symmetrically.
\end{tabular}

A cross-sectional quasi-experimental study was conducted based on a quantitative approach with a before-and-after design and a non-equivalent control group due to lack of randomization.

The study population comprised patients with hemiplegia/hemiparesis due to MCA stroke. The sample consisted of patients admitted to the Convalescence Unit (CU) and the Physical Medicine and Rehabilitation Unit (Unidade de Medicina Física e de Reabilitação, UMFR) of a hospital institution in the northern region of Portugal. The following inclusion criteria were applied: adult patients hospitalized in the selected units who, after application of the Mini-Mental State Examination, proved to have cognitive ability to understand the exercise instructions and agreed to participate in the study. Patients with impaired communication (aphasia), neuromuscular and musculoskeletal diseases affecting rehabilitation of upper limbs, dependent on self-care prior to stroke, and vision problems which prevented the observation of the mirror exercises were excluded from the study.

The sample was composed of 30 participants divided into an experimental group $(n=15)$ and a control group $(n=15)$. Due to the fact that the intervention (mirror therapy) characteristics did not allow for the implementation of a double-blind study and the fact that both units had recruited participants for both groups, the decision was made to create the 
control group in the first moment and the experimental group in a second moment. This non-random distribution, characterized by a time difference, allowed controlling for important biases resulting from the daily contacts between the participants of both groups (Fortin, 2009).

To verify the similarity and homogeneity of the sample between groups, the first part of the data collection tool included the following characterization variables: gender; age; education; type of stroke; number of stroke episodes; time elapsed since stroke; dominance of the affected upper limb; and conventional rehabilitation.

To assess the program outcomes, the second part of the data collection tool was composed of determining variables, including hand and pinch grip strength; joint range of motion of the upper limb; static sitting balance; manual dexterity/fine motor skills; pain; extinction/ inattention; and degree of self-care autonomy/ independence. Thus, the data collection tool also included: the hydraulic dynamometer to measure hand and pinch grip strength; the goniometer; the Berg Balance Scale - item 3, Portuguese version by Capucho et al. (as cited in Santos, Ramos, Estêvão, Lopes, \& Pascoalinho, 2005; validity of $r=0.93$ and reliability of $r=0.94)$; the Nine-Hole Peg Test (9HPT), which was designed in 1971 and is the most commonly used instrument in clinical practice to assess manual dexterity, with high reliability $(r=0.86-0.98$; Feys et al., 2017); the Numerical Pain Rating Scale; the National Institutes of Health Stroke Scale (NIHSS; item 11); and the GAIA (Grau de Autonomial Independência no Autocuidado, Degree of Autonomy/Independence in Self-Care) instrument designed by Couto (2012). GAIA has a good reliability, a good internal consistency (Cronbach's alpha coefficient of 0.990), and a good construct validity. In its factor analysis of the initial questions, a four-factor solution was found, which explained $86.68 \%$ of the total variance. Only the self-care assessment items of GAIA requiring greater use of the upper extremities were used, such as hygiene and grooming, bathing, feeding, and dressing/undressing. The instrument was applied to the participants in each group before and after the program. The participants in the ex- perimental group received the intervention program: self-care and mirror therapy. The participants in the control group received the conventional rehabilitation program and the placebo therapy. This therapy was composed of the same exercises, with equal frequency and duration as the mirror therapy of the intervention program, except for the use of the mirror.

The lack of human resources in research did not allow for an external evaluator to conduct a blind evaluation before and after the program. Thus, the rehabilitation nurses of both units became research partners, collaborating in data collection and in the implementation of the mirror therapy, after previous training and following the principal investigator's guidelines. These rehabilitation nurses declared that they had no conflict of interest. All ethical procedures were met. Data were processed using IBM SPSS Statistics, version 20.

\section{Results}

Below are the results obtained in the experimental and control groups in both assessment moments (before and after the program).

Inferential statistics were used to assess the differences between groups. To compare both independent groups (control and experimental) before and after the program, the Mann-Whitney $U$ test was used for numerical variables and the chi-square test $\left(X^{2}\right)$ for nominal variables. The analysis of the differences will allow assessing the contribution of mirror therapy and the effectiveness of the program. The $p$-value $(p)$ was used to identify the statistical significance of differences between groups, in which $p<0.05$ was considered statistically significant. When the differences were not significant, it could not be inferred that they occur in the target population of the intervention, being very likely $(p>0.05)$ that what was observed in the sample resulted from probability sampling, rather than from the effect of the intervention. Thus, the null hypothesis $(\mathrm{H} 0)$ was not rejected.

In the pre-program assessment (Table 2), after homogeneity was confirmed $(p>0.05)$ between groups in sociodemographic characteristics (gender, education, age), a similarity was found in the following clinical characteristics $(p>0.05)$ : 
type of stroke; number of stroke episodes; time elapsed since stroke; dominance of the affected upper limb; conventional rehabilitation; hand and pinch grip strength; range of motion of upper limb joint; static sitting balance; manual dexterity; extinction/inattention; degree of autonomy/independence in the self-care activity hygiene and grooming, self-care activity dress- ing/undressing; and most of the dimensions of the self-care activities feeding and bathing. The difference $(p<0.05)$ only occurred in pain, in the dimension Getting in/out of shower of the self-care activity bathing, and in the dimensions Chewing and Swallowing of the self-care activity feeding. Therefore, there was homogeneity between groups in most of the characteristics.

Table 2

Pre-program assessment

\begin{tabular}{|c|c|c|c|c|}
\hline \multirow[b]{2}{*}{$\begin{array}{l}\text { Sociodemographic } \\
\text { characteristics }\end{array}$} & Control group & Experimental group & $U / X^{2}$ & $p$ \\
\hline & & & & \\
\hline Gender & $\begin{array}{l}\text { Male: } 60 \% \text {; Female: } \\
40 \%\end{array}$ & $\begin{array}{l}\text { Male: } 73.3 \% \text {; Female: } \\
26.7 \%\end{array}$ & $F=0.6$ & 0.700 \\
\hline Education & $M d=6.00$ years & $M d=6.00$ years & $U=0.042$ & 0.967 \\
\hline Age & $M d=61.00$ years & $M d=59.00$ years & $U=0.830$ & 0.412 \\
\hline \multirow{2}{*}{\multicolumn{5}{|c|}{ Clinical characteristics }} \\
\hline & & & & \\
\hline Type of stroke & $\begin{array}{l}\text { Ischemic: } 66.7 \% \text {; Hem- } \\
\text { orrhagic: } 33.3 \%\end{array}$ & $\begin{array}{l}\text { Ischemic: } 86.7 \% \text {; } \\
\text { Hemorrhagic: } 13.3 \%\end{array}$ & $F=1.677$ & 0.390 \\
\hline No. of stroke episodes & $\begin{array}{l}1^{\text {st }}: 86.7 \% ; 2^{\text {nd }}: 6.7 \% \\
4^{\text {th }}: 6.7 \%\end{array}$ & 1st: $100 \%$ & $F=2.143$ & 0.343 \\
\hline $\begin{array}{l}\text { Time elapsed since } \\
\text { stroke }\end{array}$ & $M d=23.00$ days & $M d=24.00$ days & $U=0.166$ & 0.870 \\
\hline $\begin{array}{l}\text { Dominance of the } \\
\text { affected upper limb }\end{array}$ & Dominant: $46 \%$ & Dominant: $53.3 \%$ & $F=0.133$ & 1.000 \\
\hline $\begin{array}{l}\text { Conventional rehabil- } \\
\text { itation }\end{array}$ & UC: $20 \%$; UMFR: $80 \%$ & $\begin{array}{l}\text { UC: } 6.7 \% \text {; UMFR: } \\
93.3 \%\end{array}$ & $F=1.154$ & 0.598 \\
\hline Hand grip strength & $M d=0.00$ & $M d=0.00$ & $U=0.308$ & 0.758 \\
\hline Pinch grip strength & $M d=0.00$ & $M d=0.00$ & $U=0.861$ & 0.389 \\
\hline $\begin{array}{l}\text { Range of motion of } \\
\text { upper limb joint }\end{array}$ & 11 movements assessed & 11 movements assessed & - & $\begin{array}{l}\text { All move- } \\
\text { ments with } \\
p>0.05\end{array}$ \\
\hline Static sitting balance & $M d=4.00$ & $M d=4.00$ & $U=1.159$ & 0.247 \\
\hline Manual dexterity & $M d=0.00 \mathrm{~s}$ & $M d=0.00 \mathrm{~s}$ & $U=0.048$ & 0.962 \\
\hline Extinction/Inattention & $M d=0.00$ & $M d=0.00$ & $U=1.624$ & 0.104 \\
\hline $\begin{array}{l}\text { Self-care hygiene and } \\
\text { grooming }\end{array}$ & Six dimensions assessed & $\begin{array}{l}\text { Six dimensions as- } \\
\text { sessed }\end{array}$ & - & $\begin{array}{l}\text { All dimen- } \\
\text { sions with } p \\
\quad>0.05\end{array}$ \\
\hline $\begin{array}{l}\text { Self-care Dressing/ } \\
\text { undressing }\end{array}$ & Four dimensions assessed & $\begin{array}{l}\text { Four dimensions } \\
\text { assessed }\end{array}$ & - & $\begin{array}{l}\text { All dimen- } \\
\text { sions with } p \\
\quad>0.05\end{array}$ \\
\hline $\begin{array}{l}\text { Self-care bathing } \\
\text { (except dimension } \\
\text { Getting in/out of } \\
\text { shower) }\end{array}$ & Four dimensions assessed & $\begin{array}{l}\text { Four dimensions } \\
\text { assessed }\end{array}$ & - & $\begin{array}{l}\text { All dimen- } \\
\text { sions with } p \\
\quad>0.05\end{array}$ \\
\hline $\begin{array}{l}\text { Self-care feeding } \\
\text { (except dimensions } \\
\text { Chewing and swal- } \\
\text { lowing) }\end{array}$ & Four dimensions assessed & $\begin{array}{l}\text { Four dimensions } \\
\text { assessed }\end{array}$ & - & $\begin{array}{l}\text { All dimen- } \\
\text { sions with } p \\
\quad>0.05\end{array}$ \\
\hline
\end{tabular}




\begin{tabular}{lllll}
\hline Pain & $M d=5.00$ & $M d=0.00$ & $U=3.335$ & 0.001 \\
$\begin{array}{l}\text { Dimension Getting } \\
\text { in/out of shower (Self- } \\
\text { care bathing) }\end{array}$ & $M d=2.00$ & $M d=2.00$ & $U=2.087$ & 0.037 \\
$\begin{array}{l}\text { Dimension Chewing } \\
\text { (Self-care feeding) }\end{array}$ & $M d=3.00$ & -2 & & \\
$\begin{array}{l}\text { Dimension Swallow- } \\
\text { ing (Self-care feeding) }\end{array}$ & $M d=3.00$ & $M d=4.00$ & $U=2.490$ & 0.013 \\
\hline
\end{tabular}

Note. $M d=$ Median; $U=$ Mann-Whitney's $U$-test $\mathrm{X}^{2} ; F=$ Chi-square test; $p=$ probability value.

Table 3 summarizes the results of the rehabilitation gains after the program.

In the clinical variable pain, the lack of similarity in the degree of pain between groups in the first assessment made it impossible to draw any conclusions on the $p$-value $=0.001$ $(p<0.05)$ in the second assessment. It was, therefore, not possible to confirm the research hypothesis $(\mathrm{H} 5)$ on this variable.

The variable manual dexterity was monitored through the 9-HPT, in which the shorter the completion time, the higher the manual dexterity. The differences between groups were not statistically significant $(p>0.05)$; however, after the program, five participants in the experimental group completed the test, when compared to only three participants in the control group. It should be noted that only one participant in both groups completed the test before the program.

In the second assessment (after the program), although the results were not consistent with the research hypotheses, for which reason they were not corroborated (not rejecting the null hypotheses), significant differences were found in the dimension Cutting food/ spreading butter of the self-care activity Feeding, with benefits for the control group, and in the dimension Dressing/undressing lower body of the self-care activity dressing/undressing, with benefits for the experimental group. Although these statistically significant differences were only observed between groups after the implementation of the program, more significant gains were obtained in the experimental group in hand and pinch grip strength, range of motion of upper limb joint, and manual dexterity. No differences were found between groups in the remaining variables: static sitting balance; pain; extinction/inattention, and remaining self-care dimensions.

Table 3

Post-program assessment

\begin{tabular}{|c|c|c|c|c|}
\hline Program determining variables & Control group & Experimental group & $U$ & $p$ \\
\hline Hand grip strength & $M d=0.00$ & $M d=0.00$ & 0.673 & 0.501 \\
\hline Pinch grip strength & $M d=0.00$ & $M d=0.00$ & 0.792 & 0.429 \\
\hline $\begin{array}{l}\text { Range of motion of upper limb } \\
\text { joint - } 11 \text { movements }\end{array}$ & \multicolumn{2}{|c|}{$\begin{array}{l}\text { Md evolution favorable to the experimental } \\
\text { group; }\end{array}$} & - & $\begin{array}{l}\text { All move- } \\
\text { ments with } \\
p>0.05\end{array}$ \\
\hline Static sitting balance & $M d=4.00$ & $M d=4.00$ & 0.000 & 1.000 \\
\hline Manual dexterity & $M d=0.00 \mathrm{~s}$ & $M d=0.00 \mathrm{~s}$ & 1.146 & 0.252 \\
\hline Pain & $M d=4.00$ & $M d=0.00$ & 3.244 & 0.001 \\
\hline Extinction/inattention & $M d=0.00$ & $M d=0.00$ & 1.445 & 0.148 \\
\hline Self-care hygiene and grooming & \multicolumn{2}{|c|}{ Six dimensions assessed } & - & $\begin{array}{l}\text { All dimen- } \\
\text { sions with } \\
p>0.05\end{array}$ \\
\hline $\begin{array}{l}\text { Self-care dressing/undressing } \\
\text { (except dimension Dressing/un- } \\
\text { dressing lower body) }\end{array}$ & \multicolumn{2}{|c|}{ Three dimensions assessed } & - & $\begin{array}{l}\text { All dimen- } \\
\text { sions with } \\
p>0.05\end{array}$ \\
\hline
\end{tabular}




\begin{tabular}{|c|c|c|c|}
\hline Self-care bathing & Five dimensions assessed & - & $\begin{array}{c}\text { All dimen- } \\
\text { sions with } p> \\
0.05\end{array}$ \\
\hline $\begin{array}{l}\text { Self-care feeding (except dimen- } \\
\text { sion Cutting food/spreading } \\
\text { butter) }\end{array}$ & Five dimensions assessed & - & $\begin{array}{l}\text { All dimen- } \\
\text { sions with } p> \\
0.05\end{array}$ \\
\hline $\begin{array}{l}\text { Dimension Dressing/undressing } \\
\text { lower body (self-care dressing/ } \\
\text { undressing) }\end{array}$ & $M d=3.00$ & 2.157 & 0.031 \\
\hline $\begin{array}{l}\text { Dimension Cutting food/spread- } \\
\text { ing butter (self-care feeding) }\end{array}$ & $M d=3.00$ & 2.073 & 0.038 \\
\hline
\end{tabular}

Note. $M d=$ Median; $U=$ Mann-Whitney's $U$-test; $p=$ probability value.

\section{Discussion}

Sample size is similar to that used in the studies by Park et al. (2015), Gurbuz et al. (2016), and Kim et al. (2016). Wu, Huang, Chen, Lin, and Yang (2013) reported that studies should have a $n \geq 26$ per group to increase the probability of detecting significant differences $(p<0.05)$. Thus, a larger sample would allow using more powerful statistical tests (reducing the risk of making type II errors), increasing the ability to detect significant differences, even if observing a small effect (low range; Fortin, 2009).

Before the program, the groups had similar sociodemographic and clinical characteristics, which is consistent with Park et al. (2015) who found no significant differences between groups at baseline.

After rehabilitation, the analysis of the differences between groups will show that functional recovery (expressed in the study variables) contributes directly to the degree of independence in the performance of self-care activities. In hand and pinch grip strength, range of motion of upper limb joint, static sitting balance, and manual dexterity, which represent motor recovery, no significant differences were observed between groups. These results are not in line with those found by Lim et al. (2016), who found a significant impact on the recovery of motor function of the upper limb. They also contradict the results obtained by Invernizzi et al. (2013), with a sample of 26 participants in the subacute phase $( \pm 23$ days after stroke), and using the Action Research Arm Test (ARAT) and the Motricity Index (MI). The authors found more benefits in motor recovery of the upper limb when combining mirror therapy with a conventional rehabilitation program than when combining a conventional rehabilitation treatment and placebo therapy. The differences can be explained by differences in clinical characteristics, such as the type of stroke and the number of stroke episodes between the samples of both studies. Differences were also found between the studies in the total duration of application of the mirror therapy.

According to Cooke et al. (as cited in Thieme, Bayn, et al., 2012), in a sample of patients with severe distal hemiparesis of the upper limb (Medical Research Council [MRC] grading from 0 to 1 ), which was also observed in the majority of the participants in this study, it is necessary to increase the intensity and frequency of the rehabilitation program to achieve statistically significant clinical outcomes.

In relation to the data on upper limb recovery, they may partially be associated with the presence of severe distal hemiparesis of the upper limb. According to Parry et al. (as cited in Thieme, Bayn, et al., 2012), because hand function is an important predictor for functional recovery after stroke, participants had a bad prognosis for recovery, being less likely to improve, even with additional therapy.

The results on motor recovery of the upper limb are in line with those obtained by Thieme, Bayn, et al. (2012) who used the Fugl-Meyer Assessment (FMA) and the ARAT. With a similar initial characterization of the sample and total duration of the mirror therapy, no significant differences were found between the groups in both studies, after rehabilitation. In relation to pain, which was not similar between groups in the first assessment of this study, Thieme, Bayn, et al. (2012) were the only ones to investigate 
the effect of the rehabilitation program on patient-reported pain. Using the FMA item on pain, the authors found no significant differences between groups, demonstrating no positive effect in reducing pain by combining mirror therapy and the conventional rehabilitation program.

After rehabilitation, the participants had a similar evolution in terms of extinction/inattention, with a decrease in impairment in both groups. Thus, no significant difference was observed. Since it is an understudied variable, Thieme, Bayn, et al. (2012), using the Star Cancellation Test, demonstrated that the rehabilitation program using the mirror therapy had a significant positive effect on visuospatial neglect, thus confirming its effectiveness. This finding was not corroborated in the present study. In this study, this difference can be explained by the participants' limited margin of progression in the variable extinction/inattention because their pre-program assessment was close to 0 . In addition, Thieme, Bayn, et al. (2012) noted that the results have to be interpreted with caution due to the small sample size.

Despite the gains in the degree of independence, the results were similar to those found by Thieme, Bayn, et al. (2012) and Gurbuz et al. (2016), who suggested that mirror therapy had no impact on self-care due to the lack of statistically significant differences between groups observed using the Barthel Index and the Functional Independence Measure (FIM), respectively. According to Gurbuz et al. (2016), this finding may be due to the small sample size, the short duration of mirror therapy, and the fact that the majority of participants in their study had severe hemiparesis (Brunnstrom stage I or II).

With the exception of the positive effect on visuospatial neglect found by Thieme, Bayn, et al. (2012), all other findings on functional recovery were corroborated in this study, which found no differentiating effect or significant gains from using the mirror therapy, thus confirming that the functional recovery of the paretic upper limb and the performance of ADL are directly proportional (Park et al., 2015). To positively reinforce this proportionality, there are studies in this area which found benefits in the motor re- covery of the upper limb resulting from the association of the mirror therapy, as well as gains in self-care independence using both by the modified Barthel index (Lim et al., 2016) and the FIM (Invernizzi et al., 2013; Kim et al., 2016; Park et al., 2015). The latter author used FIM items such as feeding, bathing, upper and lower body dressing, and toileting, which are similar to the self-care activities and dimensions of GAIA used in this study.

Contrary to the proportionality found between the functional recovery of the upper limb and self-care autonomy, Wu et al. (2013) concluded that the sensory and motor recovery obtained after the application of the mirror therapy did not translate into gains in the performance of ADL, which were assessed using the Motor Activity Log (MAL) and ABILHAND.

The inconsistency may lie in the fact that the study focused on a chronic phase after stroke (> 6 months), contrary to the subacute phase in the remaining studies, but also in the fact that the participants received the treatment in different places. While the participants of the above-mentioned study underwent the rehabilitation program in outpatient settings, the participants in this study and in the remaining studies were hospitalized in rehabilitation centers. Outpatients could establish stable ADL routines that were less likely to change over time, making it difficult to find significant differences between groups.

The difference in mirror therapy's effectiveness between this study and other studies can result from the characteristics of the sample, such as its size, the type of stroke, the number of stroke episodes, the time elapsed since stroke, the degree of impairment of the affected upper limb, and the design of the self-care and mirror therapy program, more specifically the total duration of application of this therapy.

\section{Conclusion}

The lack of a significant difference in functional recovery between the experimental group and the control group after the program contributed to a similar degree of self-care autonomy/independence among the participants. 
Thus, with regard to the effectiveness of the self-care and mirror therapy program on the self-care autonomy of patients with hemiplegia/hemiparesis after MCA stroke, this study found that the program was not effective due to the lack of statistically significant differences between the groups.

Based on these limitations, the following suggestions are put forward: to replicate the study with a larger sample; to include participants with improved concentration capacity to focus during 1 hour on the exercises reflected in the mirror and participants with MRC $>1$ of the affected upper limb; and to redesign the self-care and mirror therapy program, namely by increasing the total duration of application of the mirror therapy to 20 hours.

Although no significant difference was observed in the implementation of the intervention, the gains found in some variables are favorable to the self-care and mirror therapy program. Due to the program's easy implementation, low cost, and possibility of implementation in home care contexts, further studies should be conducted with larger samples, controlled and randomized designs, and focused on understudied indicators such as pain, hemi-innatention, and self-care with the purpose of determining the ideal frequency and duration of the mirror therapy, as well as the ideal phase for this implementation after stroke.

Mirror therapy, as well as identical new treatment methods that may arise from new knowledge about neuroplasticity, can bring us to the next level of rehabilitation after stroke. This is a new area in nursing research for the production of disciplinary knowledge, capable of guiding future studies that will confirm, refute or expand the results obtained in this study, and contribute to an evidence-based practice closer to the real needs of the patients undergoing a process of transition from dependence to autonomy after stroke.

\section{References}

Couto, G. (2012). Autonomia/independência no Autocuidado - Sensibilidade aos Cuidados de Enfermagem de Reabilitação (Master's dissertation). Escola Superior de Enfermagem do Porto, Portugal. Retrieved from https://comum.rcaap.pt/handle/10400.26/9323.
Feys, P., Lamers, I., Francis, G., Benedict, R., Phillips, G., LaRocca, N., . . Multiple Sclerosis Outcome Assessments Consortium. (2017). The Nine-Hole Peg Test as a manual dexterity performance measure for multiple sclerosis. Multiple Sclerosis Journal, 23(5), 711-720. doi:10.1177/1352458517690824

Fortin, M. F. (2009). Fundamentos e etapas do processo de investigaçâo. Loures, Portugal: Lusodidacta.

Gurbuz, N., Afsar, S. I., Aias, S., \& Cosar, S. N. (2016). Effect of mirror therapy on upper extremity motor function in stroke patients: A randomized controlled trial. The Journal of Physical Therapy Science, 28(9), 2501-2506. doi:10.1589/jpts.28.2501

Invernizzi, M., Negrini, S., Carda, S., Lanzotti, L., Cisari, C., \& Baricich, A. (2013). The value of adding mirror therapy for upper limb motor recovery of subacute stroke patients: A randomized controlled trial. European Journal of Physical and Rehabilitation Medicine, 49(3), 311-316. Retrieved from https://www.minervamedica.it/en/getfreepdf/GKDvFURVEYx\%252BhpZ4uBeD\%252Bwzu39h1c88Omc\%252FmeX1LcSqWVe0aphnV7z1E\%252FfrXvAofODUN2DOOYGmIvRB4P3c2BQ\%253D\%253D/ R33Y2013N03A0311.pdf

Kim, K., Lee, S., Kim, D., Lee, K., \& Kim, Y. (2016). Effects of mirror therapy combined with motor tasks on upper extremity function and activities daily living of stroke patients. The Journal of Physical Therapy Science, 28(2), 483-487. doi:10.1589/jpts.28.483

Lim, K. B., Lee, H. J., Yoo, J., Yun, H. J., \& Hwang, H. J. (2016). Efficacy of mirror therapy containing functional tasks in poststroke patients. Annals of Rehabilitation Medicine, 40(4), 629-636. doi:10.5535/ arm.2016.40.4.629

Lundy-Ekman, L. (2008). Neuroscience: Fundamentals for rehabilitation ( $3^{\text {rd }}$ ed.). Philadelphia, PA: Saunders Elsevier.

Machado, S., Velasques, B., Paes, F., Cunha, M., Basile, F., Budde, H., \& Ribeiro, P. (2011). Terapia-espelho aplicada à recuperação funcional de pacientes pósacidente vascular cerebral. Revista Neurociências, 9(1), 171-175. Retrieved from http://www.revistaneurociencias.com.br/edicoes/2011/RN1901/opiniao\%20 e\%20rev\%20aberta/586\%20opiniao.pdf

Meleis, A. (2007). Theoretical nursing: Development and progress (4 $4^{\text {th }}$ ed.). Philadelphia, PA: Lippincott Williams \& Wilkins.

Organização Mundial de Saúde. (2009). Manual STEPS de acidentes vascular cerebrais da OMS: Enfoque passo a passo da OMS para a vigilancia de acidentes vasculares cerebrais. Retrieved from http://www1.paho.org/hq/ dmdocuments/2009/manualpo.pdf

Park, Y., Chang, M., Kim, K., \& An, D. (2015). The effects 
of mirror therapy with tasks on upper extremity function and self-care in stroke patients. Journal of Physical Therapy Science, 27(5), 1499-1501. doi:10.1589/ jpts.27.1499

Ramachandran, V. S., \& Rogers-Ramachandran, D. (1996). Synesthesia in phantom limbs induced with mirror. Proceedings Biological Sciences, 263(1369), 377-386. doi:10.1098/rspb.1996.0058

Ribeiro, O., Pinto, C., \& Regadas, S. (2014). A pessoa dependente no autocuidado: Implicaçóes para a enfermagem. Revista de Enfermagem Referência, 4(1), 25 36. doi:10.12707/RIII12162

Santos, A., Ramos, N., Estêvão, P., Lopes, A., \& Pascoalinho, J. (2005). Instrumentos de Medida Úteis no Contexto da Avaliação em Fisioterapia. Re(habilitar) - Revista da ESSA, 1, 131-156.

Thieme, H., Mehrholz, J., Pohl, M., Behrens, J., \& Dohle, C. (2012). Mirror therapy for improving motor function after stroke. Cochrane Database Systematic Reviews,
14(3). doi:10.1002/14651858.CD008449.pub2

Thieme, H., Bayn, M., Wurg, M., Zange, C., Pohl, M., \& Behrens, J. (2012). Mirror therapy for patients with severe arm paresis after stroke: A randomized controlled trial. Clinical Rehabilitation, 27(4), 314-324. doi:10.1177/0269215512455651

Umphred, D. (2010). Reabilitação neurológica (5a ed.). Rio de Janeiro, Brasil: Elsevier.

Wu, C. Y., Huang, P. C., Chen, Y. T., Lin, K. C., \& Yang, H. W. (2013). Effects of mirror therapy on motor and sensory recovery in chronic stroke: A randomized controlled trial. Archives of Physical Medicine and Rehabilitation, 94(6), 1023-1030. doi:10.1016/j. apmr.2013.02.007

Zeng, W., Guo, Y., Wu, G., Liu, X., \& Fang, Q. (2018). Mirror therapy for motor function of the upper extremity in patients with stroke: A meta-analysis. Journal of Rehabilitation Medicine, 50(1), 8-15. doi:10.2340/16501977-2287 
